\title{
Pengaruh Model Pembelajaran Kooperatif Tipe STAD (Student Team Achievement Division) dengan Metode Eksperimen Terhadap Keterampilan Proses Sains dan Hasil Belajar Fisika pada Siswa SMA Negeri 1 Labuapi Tahun Pelajaran 2015/2016
}

\author{
Juraini $^{1}$, Muhammad Taufik ${ }^{1}$, I Wayan Gunada ${ }^{1}$ \\ ${ }^{1}$ Program Studi Pendidikan Fisika \\ FKIP Universitas Mataram \\ Mataram, Indonesia \\ Email: jurainid@yahoo.co.id
}

\begin{abstract}
This study is aimed to know the influence of cooperative learning type STAD by experiment method towards science process skill and student's output in learning physics at SMAN 1 Labuapi in academic year 2015/2016. The method used in this study was quasi experimental design of untreated control group design pretest-posttest. The population of this study was the overall students of X class at SMAN 1 Labuapi, where there are 4 classes with random sampling technique in taking the subject. Two sample was taken as the subject of this study where X-D as experimental class which was treated using cooperative learning of type STAD by experiment method and X-A as control class. Technique of data analysis of this study was two sample t-test. Based on the result of this study, it can be concluded: (1) there was the influence of cooperative learning of type STAD by experiment method towards science process skill of student's physics, (2) there was the influence of cooperative learning of type STAD by experiment method towards student's output in learning physics.
\end{abstract}

Keywords: Cooperative Learning of Type STAD, Experiment Method, Science Process Skill, Learning Output

\section{Pendahuluan}

Pendidikan dapat dimaknai sebagai proses mengubah tingkah laku siswa agar menjadi manusia dewasa yang mampu hidup mandiri dan sebagai anggota masyarakat dalam lingkungan alam sekitar dimana individu itu berada. Pendidikan tidak hanya mencakup pengembangan intelektualitas saja, akan tetapi lebih ditekankan pada proses pembinaan kepribadian siswa secara menyeluruh sehingga siswa menjadi lebih dewasa. Sehingga, dalam dunia pendidikan bahwa keberhasilan dalam pembelajaran ditentukan dengan kualitas dan mutu pendidikan, khususnya di sekolah. Salah satu upaya untuk meningkatkan mutu pendidikan dan keberhasilan siswa dalam mempelajari fisika adalah dengan cara memperbaiki proses pembelajaran.

Proses pembelajaran yang di maksud adalah dengan memperbaiki cara mengajar dengan mengggunakan model pembelajaran dan metode yang sesuai dengan materi fisika. Ada banyak model dan metode pembelajaran yang dikembangkan para ahli dalam mengoptimalkan hasil belajar. Akan tetapi, bukan berarti semua model dan metode pengajar menerapkan semuanya untuk setiap mata pelajaran karena tidak semua model dan metode cocok untuk setiap materi fisika. Oleh sebab itu, bukan hal mudah bagi guru memilih model dan metode yang sesuai dengan materi dalam mengajar, karena di dalam setiap kelas dipenuhi oleh kemampuan akademik siswa yang heterogen. Jika seorang guru mampu memilih model dan metode pembelajaran sesuai. Maka, siswa yang belajar dengan model pembelajaran yang tepat akan mengalami perubahan ke arah yang lebih baik, baik dari segi pengetahuan, keterampilan maupun sikap. Sehingga, seorang guru dapat menciptakan proses pembelajaran yang aktif, kreatif, efektif, inovatif dan menyenangkan yang mampu mengajak siswa untuk memahami materi pelajaran fisika dan aplikasinya dalam kehidupan sehari-hari dengan mudah.

Berdasarkan hasil observasi yang dilakukan di SMA Negeri 1 Labuapi bahwa Salah seorang guru mengatakan bahwa proses pengajaran yang diterapkan pada materi fisika masih berpusat pada guru dan hanya diberi konsep tanpa ada proses ilmiah atau tanpa melakukan eksperimen untuk menemukan konsep-konsep tersebut. Sehingga siswa bahwa fisika merupakan pelajaran yang dipenuhi oleh rumusrumus yang dan kurang menarik untuk dipelajari.

Berdasarkan penjelasan di atas, maka upaya mengatasi permasalahan pembelajaran tersebut diperlukan model pembelajaran yang bervariasi mengarahkan siswa untuk aktif dan minat siswa belajar fisika dalah model pembelajaran kooperatif tipe STAD. Pembelajaran kooperatif tipe STAD ini merupakan salah satu tipe dari model pembelajaran kooperatif dengan menggunakan kelompokkelompok kecil dengan jumlah anggota tiap kelompok 4-5 orang siswa secara heterogen. Diawali dengan penyampaian tujuan pembelajaran, penyampaian materi, kegiatan kelompok, kuis, dan penghargaan kelompok [1].

Berdasarkan uraian di atas maka peneliti tertarik melakukan penelitian yang berjudul "Pengaruh 
Model Pembelajaran Kooperatif Tipe STAD (Student Team Achievement Division) dengan Metode Eksperimen Terhadap Keterampilan Proses Sains dan Hasil Belajar Fisika pada Siswa SMA Negeri 1 Labuapi Tahun Pelajaran 2015/2016".

Sesuai dengan permasalahan yang telah dirumuskan diatas, maka tujuan penelitian ini adalah: 1) untuk mengetahui pengaruh model pembelajaran kooperatif tipe STAD dengan metode eksperimen terhadap keterampilan proses sains fisika siswa SMA Neeri 1 Labuapi tahun pelajaran 2015/2016; 2) untuk mengetahui pengaruh model pembelajaran kooperatif tipe STAD dengan metode eksperimen terhadap hasil belajar fisika siswa SMA Negeri 1 Labuapi tahun pelajaran 2015/2016. Hasil penelitian ini diharapkan bermanfaat bagi siswa, guru, peneliti serta lembaga pendidikan tenaga keguruan yang ingin mengambil kajian yang sama guna meningkatkan keterampilan proses sains dan hasil belajar fisika siswa.

\section{TINJAUAN PUSTAKA}

\section{A. Model Pembelajaran Kooperatif Tipe STAD}

Pembelajaran kooperatif tipe STAD juga membutuhkan persiapan yang matang sebelum kegiatan pembelajaran dilaksanakan. Dalam menentukan kelompok diusahakan agar kemampuan siswa dalam kelompok adalah heterogen dan kemampuan antar satu kelompok lainnya relative homogen [2]. Tipe STAD ini dikembangkan Slavin, dan menekankan pada adanya aktivitas dan interaksi dan saling membantu dalam menguasai materi pelajaran guna mencapai prestasi yang maksimal [3].

Model pembelajaran kooperatif tipe STAD memiliki kelebihan antara lain: 1) meningkatkan motivasi belajar siswa dalam belajar; 2) meningkatkan prestasi belajar siswa dan kreativitas siswa; 3) mendengar, menghormati, serta menerima pendapat orang lain [4].

Model pembelajaran koopertif tipe STAD merupakan model pembelajaran yang paling sederhana dan model ini salah satu bagian dari pembelajaran kooperatif yang menekankan pada kegiatan kerjasama kelompok sekaligus tanggung jawab perorangan untuk mencapai suatu keberhasilan dalam kegiatan pembelajaran.

\section{B. Metode Eksperimen}

Metode eksperimen adalah cara penyajian bahan pelajaran di mana siswa melakukan percobaan dengan mengalami untuk membuktikan sendiri sesuatu pertanyaan atau hipotesis yang dipelajari. Peran guru dalam metode ini sangat penting, khususnya berkaitan dengan ketelitian dan kecermatan sehingga tidak terjadi kekeliruan dan kesalahan dalam memaknai kegiatan eksperimen dalam kegiatan belajar [5].

Metode eksperimen merupakan suatu bentuk pengajaran yang memberikan pengalaman langsung kepada siswa untuk melakukan percobaan guna membuktikan sesuatu yang sedang dipelajari oleh siswa.

\section{Keterampilan Proses Sains}

Keterampilan proses sains sangat penting dilatihkan atau dikembangkan dalam pembelajaran, karena dengan memiliki keterampilan proses sains siswa lebih memahami apa yang dipelajarinya, karena siswa tidak hanya sekedar memperoleh pengetahuan akan tetapi menemukan pengetahuanya itu sendiri. Melatihkan keterampilan proses merupakan salah satu upaya yang penting untuk memperoleh keberhasilan belajar siswa yang optimal. Materi pelajaran akan lebih mudah dipelajari, dipahami, dihayati, dan diingat dalam waktu yang relatif lama bila siswa sendiri memperoleh pengalaman langsung [6].

Keterampilan proses sains adalah keterampilan pembelajaran yang menfokuskan pembelajaran pada pengembangan keterampilan siswa dalam memproseskan pengetahuan, menemukan dan mengembangkan sendiri fakta, konsep, dan nilai-nilai yang diperlukan. Keterampilan proses sains terdiri atas keterampilan dasar (basic skill) dan keterampilan terintegrasi (integrated skill).

\section{Hasil Belajar}

Hasil belajar merupakan pola-pola perbuatan, nilai-nilai, pengertian-pengertian, sikap-sikap, apresiasi dan keterampilan. Sedangkan, Tujuan pendidikan yang ingin dicapai dapat dikategorikan menjadi tiga bidang yakni bidang kognitif, bidang afektif dan bidang psikomotor [7].

Hasil belajar fisika siswa adalah kemampuan siswa setelah mengikuti proses pembelajaran fisika terlihat dari perubahan sikap, pengetahuan dan keterampilan siswa yang dibandingkan dengan sebelum belajar.

\section{METODE PENELITIAN}

Jenis penelitian yang digunakan adalah eksperimen semu, yang merupakan suatu cara untuk menguji hubungan sebab, dimana peneliti memberikan perlakuan kepada subjek untuk menentukan apakah perlakuan tersebut memiliki dampak atau pengaruh pada variabel atau faktor hasil tertentu [8]. Penelitian ini dilaksanakan pada Oktober 2015 sampai dengan Juni 2016. Tempat pelaksanaan penelitian di SMA Negeri 1 Labuapi. Penelitian ini melibatkan tiga variabel utama yang mengfokuskan pada variabel bebas, terikat dan control. Variabel bebas pada penelitian ini adalah model pembelajaran kooperatif tipe STAD dengan metode eksperimen, Variabel terikat adalah keterampilan proses sains dan hasil belajar. Variabel kontrol adalah materi, tujuan pembelajaran, silabus, RPP, LKS dan Cara penilaian. Desain penelitian yang digunakan adalah desain 
kelompok non ekuivalen atau disebut juga untreated control group design with pretest and posttest yang bertujuan untuk memperoleh perbedaan keterampilan proses sains dan hasil belajar fisika siswa antara kelas eksperimen dan kelas kontrol.

Adapun Teknik pengambilan sampel yang digunakan adalah random sampling. Melalui random sampling didapatkan dua kelas yang terpilih secara acak. Sampel hasil yang didapatkan adalah kelas X-D dengan jumlah 20 orang sebagai kelas eksperimen dan siswa kelas X-A dengan jumlah 19 orang sebagai kelas kontrol.

Tehnik pengumpulan data dilakukan dengan metode tes dan non tes. Metode pengumpulan data keterampilan proses sains yang digunakan dalam penelitian ini adalah tes observasi merupakan metode non tes. Metode tes menggunakan tes hasil belajar fisika. Data hasil belajar fisika merupakan data pretest sebelum diberikan perlakuan dan data posttest diperoleh menggunakan instrumen yang diujicobakan kepada 20 siswa kelas XI IPA 2 yang sudah menerima materi listrik dinamis sebelumnya, kemudian hasil belajar tersebut dianalisis dengan uji validitas, realibilitas, tingkat kesukaran dan daya beda soal. Berdasarkan hasil uji coba 30 butir soal diperoleh 22 soal yng baik digunakan untuk pretest dan posttest. Analisis validitas soal menggunakan rumus product moment dan untuk uji realibilitas soal mengunakan rumus Spearman-Borwn, indeks kesukaran soal untuk tingkat kesukaran soal dan indeks diskriminasi untuk daya beda soal. Analisis data menggunakan statistik parametrik t-test polled varians dengan kriteria uji dua pihak, yang sebelumnya telah diuji normalitas data menggunakan uji chi kuadrat dan homogenitas data menggunakan uji $\mathrm{F}$.

\section{HASIL DAN PEMBAHASAN}

Hasil penelitian berupa data keterampilan proses sains dan hasil belajar fisika. Keterampilan proses sains akan di nilai saat kegiatan pembelajaran yang akan dinilai oleh observer. Data pretest dan posttest merupakan data hasil belajar fisika. Data keterampilan proses sains dan hasil belajar fisika dengan menggunakan uji homogenitas, uji normalitas dan uji hipotesis ( $t$-test polled varians).

Aspek keterampilan proses sains siswa pada kelas eksperimen saat proses pembelajaran yang muncul lebih banyak dari pada kelas kontrol. Hal ini dikarenakan pada kelas eksperimen menggunakan model pembelajaran kooperatif tipe STAD dengan metode eksperimen sedangkan kelas kontrol menggunakan model pembelajaran konvesional. Adapun nilai rata-rata tiap aspek keterampilan proses sains pada kelas eksperimen dan kelas kontrol dapat terlihat pada gambar 1 berikut ini.

Gambar 1. Histogram Keterampilan Proses Sains Siswa Tiap Indikator pada Kelas Ekperime dan Kelas Kontrol

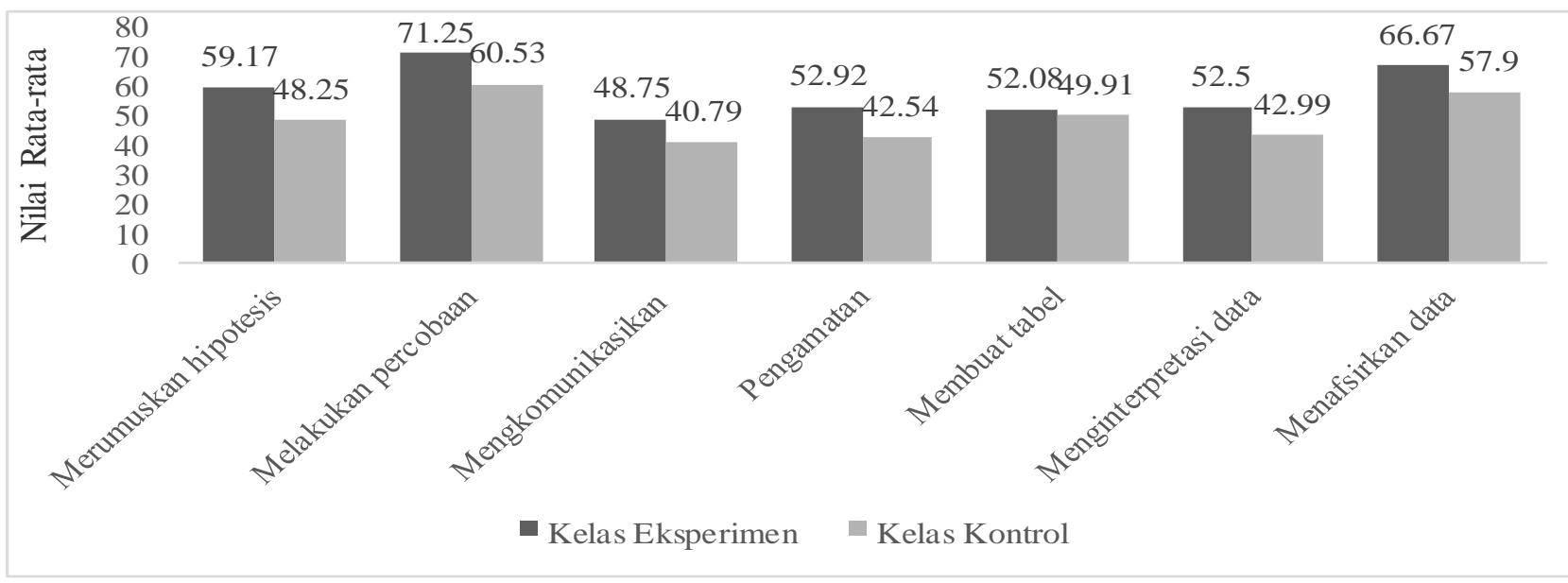

Berdasarkan gambar 1, dapat terlihat bahwa nilai tiap aspek keterampilan proses sains pada kelas eksperimen lebih meningkat dibandingkan kelas kontrol. Setiap aspek keterampilan proses sains pada kelas eksperimen dari tertinggi sampai terendah pada masing-masing aspek diantaranya melakukan percobaan, menafsirkan data, merumuskan hipotesis, pengamatan, menginterprestasi data, membuat tabel dan mengkomunikasikan. Sedangkan pada kelas kontrol aspek keterampilan proses sains pada masingmasing aspek diantaranya melakukan percobaan, menafsirkan data, merumuskan hipotesis, menginterprestasi data, pengamatan, mengkomunikasikan, membuat tabel.

Pada kelas eksperimen diketahui aspek keterampilan proses sains yang paling baik yaitu melakukan percobaan, hal ini dikarenakan siswa dapat melakukan percobaan dengan antusias dan 
serius sehingga observer bisa menilai secara objektif berdasarkan saat proses pembelajaran sedangkan aspek keterampilan proses sains yang kurang baik adalah mengkomunikasikan, ini dikarenakan siswa dalam satu kelompok tersebut hanya sebagian yang melakukan presentasi di depan kelas dan membuat laporan. Pada kelas kontrol diketahui bahwa aspek keterampilan proses sains yang paling baik adalah melakukan percobaan. Sama halnya pada kelas eksperimen, akan tetapi dengan melihat nilai rata-rata lebih baik pada kelas eksperimen dibandingkan kelas kontrol. Sedangkan aspek keterampilan proses sains yang kurang baik pada kelas kontrol adalah membuat tabel, hal ini disebabkan siswa kurang mampu menuliskan hasil pengukuran pada tabel hasil percobaan secara baik dan masih menanya pada guru cara menuliskan perhitungan yang dimasukan pada tabel tersebut.

Berdasarkan hasil observasi yang dilakukan oleh observer akan terlihat rekapitulasi data keterampilan proses sains pada kelas eksperimen dan kelas kontrol pada tabel 1 berikut ini:

Tabel 1. Rekapitulasi data keterampilan proses sains pada kedua sampel

\begin{tabular}{lcc}
\hline \multicolumn{1}{c}{ Komponen } & $\begin{array}{c}\text { Kelas } \\
\text { Eksperimen }\end{array}$ & $\begin{array}{c}\text { Kelas } \\
\text { Kontrol }\end{array}$ \\
\hline Jumlah Siswa & 20 & 19 \\
Nilai tertinggi & 80 & 70 \\
Nilai terendah & 40 & 35 \\
Rata-rata & 57.62 & 47.56 \\
Standar Deviasi & 12.29 & 10.55 \\
(SD) & & \\
Uji Normalitas & Normal & Normal \\
Uji & Homogen & Homogen \\
Homogenitas & \multicolumn{2}{c}{$<\mathrm{t}_{\text {tabel }}<\mathrm{t}_{\text {hitung }}>\mathrm{t}_{\text {tabel }}$} \\
Uji Hipotesis & $\mathrm{H}_{0}$ ditolak dan $\mathrm{H}_{\mathrm{a}}$ diterima \\
\hline
\end{tabular}

Berdasarkan tabel 1, terlihat bahwa nilai rata-rata keterampilan proses sains dengan menggunakan model pembelajaran kooperatif tipe STAD dengan metode eksperimen memiliki rentang yang begitu cukup jauh, sebesar 10,59. Dianalisis menggunakan uji hipotesis diperoleh nilai $\mathrm{t}_{\text {hitung }}>\mathrm{t}_{\text {tabel }}$ yaitu $2,73>$ 2,03 sehingga hipotesis nol ditolak dan hipotesis alternatif diterima, maka terdapat pengaruh model pembelajaran kooperatif tipe STAD dengan metode eksperimen terhadap keterampilan proses sains. Adanya perubahan rata-rata pada keterampilan proses sains siswa memperlihatkan bahwa penerapan model pembelajaran kooperatif dengan metode eksperimen di kelas eksperimen memberikan pengaruh positif terhadap keterampilan proses sains. Seperti halnya dengan penelitian yang menggatakan bahwa model pembelajaran inkuiri terbimbing dapat berpengaruh terhadap keterampilan proses sains fisika siswa [9].
Dampak positif pada keterampilan proses sains siswa di kelas eksperimen muncul karena tahap-tahap dalam model pembelajaran kooperatif tipe STAD yang dipadukan eksperimen dapat mengembangkan keterampilan proses sains siswa. Pada tahap penyampaian memotivasi, siswa akan terlihat bersemangat untuk menjawab pertanyaan yang diajukan oleh guru. Sehingga terlihat rasa ingin tahu siswa yang terkait dengan materi listrik dinamis dan selanjutnya akan terlihat keterampilan proses sains siswa pada saat tahap kelompok bekerja dan belajar siswa akan melakukan eksperimen. Pada tahap akhir model pembelajaran kooperatif tipe STAD yaitu pemberian penghargaan dengan tahap akhir siswa menjadi lebih terpacu untuk meraih hasil yang terbaik. Pemberian penghargaan ini, siswa diberikan hadiah bagi 3 kelompok yang terbaik dalam melakukan eksperimen. Hal ini sesuai dengan penelitian yang menggatakan bahwa model pembelajaran inkuiri ilmiah dapat berpengaruh terhadap keterampilan proses sains fisika siswa [10].

Data hasil belajar fisika dengan menggunakan uji homogenitas, uji normalitas dan uji hipotesis (t-test polled varians). Adapun rekapitulasi data pretest pada kelas eksperimen dan kelas kontrol pada materi listrik dinamis dapat terlihat pada tabel 2 berikut ini:

Tabel 2. Rekapitulasi data pretest pada kedua sampel

\begin{tabular}{lcc}
\hline \multicolumn{1}{c}{ Komponen } & $\begin{array}{c}\text { Kelas } \\
\text { Eksperimen }\end{array}$ & $\begin{array}{c}\text { Kelas } \\
\text { Kontrol }\end{array}$ \\
\hline Jumlah Siswa & 20 & 19 \\
Nilai tertinggi & 64 & 64 \\
Nilai terendah & 32 & 32 \\
Rata-rata & 49.50 & 46.75 \\
Standar Deviasi & 11.47 & 10.67 \\
(SD) & & \\
Uji Normalitas & Normal & Normal \\
Uji & Homogen & Homogen \\
Homogenitas & - $\mathrm{t}_{\text {tabel }}<\mathrm{t}_{\text {hitung }}>\mathrm{t}_{\text {tabel }}$ \\
Uji Hipotesis & $\mathrm{H}_{0}$ ditolak dan $\mathrm{H}_{\mathrm{a}}$ diterima \\
\hline
\end{tabular}

Berdasarkan tabel 2, menunjukkan bahwa nilai rata-rata pretest siswa pada kedua sampel sebesar 49,50 untuk kleas eksperimen dan 46,75 untuk kelas kontrol. Berdasarkan hasil penelitian tersebut bahwa kelas eksperimen dan kelas kontrol homogen yang berarti kedua sampel memiliki kemampuan yang sama. Selain itu, hasil rata-rata tes awal yang rendah disebabkan karena siswa pada kedua kelompok sampel belum mendapatkan pembelajaran mengenai materi listrik dinamis. Oleh karena itu, siswa belum memiliki pemahaman memadai untuk menjawab soal-soal pretest yang diberikan.

Setelah dilakukan pretest selanjutnya kedua sampel diberikan perlakuan yang berbeda-beda., dimana kelas eksperimen diberikan perlakuan dengan 
model pembelajaran kooperatif tipe STAD dengan metode eksperimen sedangkan kelas kontrol diberikan perlakuan dengan metode pembelajaran konvesional. Berdasarkan hasil posttest siswa nilai rata-rata mengalami peningkatan. Seperti yang terlihat pada tabel 3 berikut ini:

Tabel 3. Rekapitulasi data posttest pada kedua

\begin{tabular}{|c|c|c|}
\hline Komponen & $\begin{array}{c}\text { Kelas } \\
\text { Eksperimen }\end{array}$ & $\begin{array}{c}\text { Kelas } \\
\text { Kontrol }\end{array}$ \\
\hline Jumlah Siswa & 20 & 19 \\
\hline Nilai tertinggi & 91 & 86 \\
\hline Nilai terendah & 50 & 50 \\
\hline Rata-rata & 74.20 & 65.78 \\
\hline $\begin{array}{l}\text { Standar Deviasi } \\
\text { (SD) }\end{array}$ & 11.35 & 10.11 \\
\hline Uji Normalitas & Normal & Normal \\
\hline $\begin{array}{l}\text { Uji } \\
\text { Homogenitas }\end{array}$ & Homogen & Homogen \\
\hline Uji Hipotesis & \multicolumn{2}{|c|}{$\begin{array}{c}-\mathrm{t}_{\text {tabel }}<\mathrm{t}_{\text {hitung }}>\mathrm{t}_{\text {tabel }} \\
\mathrm{H}_{0} \text { ditolak dan } \mathrm{H}_{\mathrm{a}} \text { diterima }\end{array}$} \\
\hline
\end{tabular}

Pada kelas eksperimen dan kelas kontol setelah diberikan perlakuan, terjadi peningkatan hasil belajar fisika siswa. Nilai rata-rata posttest siswa kelas eksperimen 74.20 sedangkan kelas kontrol 65.78. Hasil posttest pada kedua sampel menunjukkan suatu perbedaan yang signifikan, peningkatan yang lebih tinggi daripada kelas kontrol. Hal ini sesuai dengan penelitian yang menggatakan bahwa dengan menerapkan model pembelajaran kooperatif tipe STAD dengan metode berpengaruh pada hasil belajar siswa [11].

Berdasarkan hasil analisis uji hipotesis diperoleh nilai $\mathrm{t}_{\text {hitung }}>\mathrm{t}_{\text {tabel }}$ yaitu 2,63>2,03 sehingga hipotesis nol ditolak dan hipotesis alternatif diterima, maka terdapat pengaruh model pembelajaran kooperatif tipe STAD dengan metode eksperimen terhadap hasil belajar fisika siswa. Model pembelajaran kooperatif merupakan model pembelajaran yang dapat mengaktifkan siswa dan bekerjasama dalam menyelesaiakan tugas. Model pembelajaran kooperatif tipe STAD ini sangat cocok dipadukan dengan metode eksperimen karena ketika siswa melakukan eksperimen, maka siswa mendapat pengalaman langsung itu akan tertanam dan menguatkan ingatan siswa tentang konsep-konsep dan penerapan fisika yang dipelajarinya pada materi listrik dinamis. Hal ini yang menunjukkan bahwa terdapat pengaruh terhadap hasil belajar fisika siswa saat pembelajaran kooperatif tipe STAD yang berorientasi kurikulum 2013 dengan metode eksperimen diterapkan [12]. Berdasarkan hasil uji hipotesis berpengaruh terhadap hasil belajarnya ketika diberikan tes. Hal ini sesuai dengan peneliti yang menunjukkan bahwa terdapat pengaruh terhadap hasil belajar fisika siswa saat pembelajaran kooperatif tipe STAD diterapkan [13].

\section{PENUTUP}

Berdasarkan hasil penelitian dan pembahasan, maka dapat disimpulkan beberapa hal; 1) terdapat pengaruh model pembelajaran kooperatif tipe STAD dengan metode eksperimen terhadap keterampilan proses sains fisika pada siswa SMA Negeri 1 Labuapi tahun pelajaran 2015/2016; 2) terdapat pengaruh model pembelajaran kooperatif tipe STAD dengan metode eksperimen terhadap hasil belajar fisika pada siswa SMA Negeri 1 Labuapi tahun pelajaran 2015/2016.

Model pembelajaran kooperatif tipe STAD dengan metode eksperimen dapat dijadikan sebagai alternatif model pembelajaran yang dapat diterapkan untuk mengaktifkan siswa, sehingga hasil belajar kognisi siswa meningkat. Dalam menerapkan model pembelajaran kooperatif tipe STAD dengan metode eksperimen perlu diperhatikan beberapa hal, yaitu; 1) alokasi waktu diatur sebaik mungkin sehingga tiap tahapan pembelajaran dapat berlangsung secara optimal; 2) alat dan bahan eksperimen disiapkan sebaik-baiknya.

\section{UCAPAN TERIMA KASIH}

Terima kasih penulis sampaikan kepada Bapak Dr. Wildan, M.Pd., Dr. Drs. Karnan, M.Si. Dr. Ahmad Harjono, S.Si., M.Pd., Serta pihak yang telah membantu penelitian ini.

\section{REFERENSI}

[1] Trianto. 2011. Model-model Pembelajaran Inovatif Berorientasi Konstruktivistik Konsep, Landasan Teoritis-Praktis dan Implementasinya. Jakarta: Prestasi Pustaka.

[2] Huda, M. 2013. Model-Model Pengajaran dan Pembelajaran Isu-isu Metodis dan Pragmatis. Yogyakarta: Pustaka Pelajar.

[3] Lindarti, Hinduan A.A Dan Oktova, R. 2010 "Penerapan Pembelajaran Kooperatif STAD (Students Teams Achievement Division) Dalam Upaya Meningkatkan Hasil Belajar Fisika Pada Konsep Optika Geometris kelas X SMA”. Jurnal Berkala Fisika Indonesia. Vol. 2 No. 2 Hal. 2938.

[4] Roslimah dan Muhibbudin. 2014. "Penerapan Model Pembelajaran STAD (Student Teams Achievement Divisions) Untuk meningkatkan Hasil Belajar dan Kemampuan Pemetaan Konsep Siswa Pada Materi Ekosistem". Jurnal EduBio Tropika. Vol. 2 No. 2 Hal. 187-250.

[5] Sagala, S. 2013. Konsep dan Makna Pembelajaran Untuk Membantu Memecahkan Problematika Belajar dan Mengajar. Bandung: Alfabeta CV.

[6] Rustaman, N.Y. 2007. Keterampilan Proses Sains. Bandung: UPI.

[7] Supriyono, A. 2012. Cooperative Learning Teori \& Aplikasi PAIKEM. Yogyakarta: Pustaka Pelajar. 
[8] Setyosari, P. 2013. Metode Penelitian Pendidikan dan Pengembangan. Jakarta: Kencana Prenadamedia Group.

\section{Biografi Penulis}

[9] Eko, L. dan Imam, S. 2013. "Pengaruh Model Pembelajaran Inkuiri Terbimbing Pada Pokok Bahasan Kalor Keterampilan Proses Sains Terhadap Hasil Belajar Di SMAN 1 Sumenep". Jurnal Inovasi Pendidikan Fisika. Vol. 2 No. 2 Hal. 62-65.

Juraini, lahir didesa Bre Kab.Bima, 11 Nopember 1994. Penulis telah menyelesaikan pendidikan di SDN Impres Bre, SMPN 3 Woha dan SMAN 3 Kota Bima, kemudian melanjutkan studinya di FKIP Universitas Mataram pada Progran Studi Pendidikan

0] Muslim, K. dan Fransisca, S.T. 2015. "Pengaruh Model Pembelajaran Inkuiri Ilmiah Terhadap Peningkatan Keterampilan Proses Sains Siswa SMP pada Materi Kalor dalam Kehidupan”. EDUSAINS. Vol. VII No. 1 Hal. 88-96.

[11] Yunita, A dan Amdani, K. 2014. “. Pengaruh Model Pembelajaran Kooperatif Tipe Student Teams Achievement Division (STAD) dengan Metode Eksperimen Terhadap. Hasil Belajar Siswa Pada Materi Listrik Dinamis Kelas X SMA Dharmawangsa Medan Tahun Pelajaran 2012/2013". Inpafi. Vol. 2 No.1 Hal. 21-26.

[12] Putri, A dan Retno H. 2015." Pengaruh Model Pembelajaran Kooperatif Tipe STAD yang berorientasi Kurikulum 2013 dengan Metode Eksperimen terhadap Hasil Belajar Siswa Pada Konsep Materi Pengukuran di Kelas X SMAN 2 Sidoarjo". Jurnal Inovasi Pendidikan fisika. Vol. 04 No. 1 Hal. 36-41.

[13] Lubis, A. 2012. Pengaruh Pembelajaran Kooperatif Tipe STAD Terhadap Hasil Belajar Fisika Siswa pada Materi Pokok Gerak Lurus di Kelas X SMA UISU Medan. Jurnal Pendidikan Fisika. Vol. 1, No. 1.

Fisika Angkatan 2012 dan lulus pada Juli 2016.

Muhammad Taufik, S.Pd,.M.Si, lahir di Medan, 23 Maret 1971. Telah menyelesaikan pendidikan S-1 pada prodi pendidikan Fisika IKIP Medan pada tahun 1993 dan menyelesaikan pendidikan S-2 pada prodi Fisika UGM Yogyakarta pada tahun 1999. Saat ini masih menjadi dosen pendidikan Fisika FKIP Universitas Mataram.

I Wayan Gunada, S.Si., M.Pd. Lahir di Baturiti, 15 Agustus 1975. Telah menyelesaikan pendidikan S-1 pada prodi Fisika Universitas Udayana pada tahun 2000 dan menyelesaikan pendidikan S-2 pada program studi Penelitian dan Evaluasi Pendidikan Universitas Pendidikan Ganesha, Singaraja pada tahun 2010. Saat ini masih menjadi dosen pendidikan Fisika FKIP Universitas Mataram. 